\title{
GCU
}

Glasgow Caledonian

University

University for the Common Good

\section{Exploring dynamic natural-resource-based capabilities for sustainable agri-food chains}

McDougall, Natalie; Wagner, Beverly ; MacBryde, Jillian

Published in:

Sustainable Design and Manufacturing

DOI:

10.1007/978-3-319-32098-4_39

Publication date:

2016

Document Version

Author accepted manuscript

Link to publication in ResearchOnline

Citation for published version (Harvard):

McDougall, N, Wagner, B \& MacBryde, J 2016, Exploring dynamic natural-resource-based capabilities for sustainable agri-food chains. in Sustainable Design and Manufacturing . vol. 52, Smart Innovation, Systems \& Technologies , Springer, pp. 455-465. https://doi.org/10.1007/978-3-319-32098-4_39

\section{General rights}

Copyright and moral rights for the publications made accessible in the public portal are retained by the authors and/or other copyright owners and it is a condition of accessing publications that users recognise and abide by the legal requirements associated with these rights.

Take down policy

If you believe that this document breaches copyright please view our takedown policy at https://edshare.gcu.ac.uk/id/eprint/5179 for details

of how to contact us. 


\title{
Exploring Dynamic Natural-Resource-Based Capabilities for Sustainable Agri-Food Chains
}

\author{
Natalie McDougall ${ }^{1}$, Beverly Wagner ${ }^{1}$, and Jillian MacBryde ${ }^{2}$ \\ ${ }^{1}$ University of Strathclyde Business School, Glasgow, UK \\ \{natalie.mcdougall, beverly.wagner\}@strath.ac.uk \\ 2 The York Management School, University of York, York, UK \\ jill.macbryde@york.ac.uk
}

\begin{abstract}
The natural-resource-based-view (NRBV) is positively presented in literature as a competitive approach to sustainable operations. In spite of this the theory has struggled to transition into industry; something which academics attribute to a lack of practical guidance and ill-defined capabilities. The purpose this study is to identify NRBV capabilities. This is done via review of seminal NRBV studies and exploration of a synergistic relationship with SSCM, permitting the identification of potentially relevant capabilities. Dynamic capabilities theory is then applied to categorize the capabilities and further enhance applicability. A qualitative multiple-interview methodological approach is employed to empirically investigate the capabilities within the context of the Scottish agrifood sector.
\end{abstract}

Keywords: natural resource based view $\cdot$ sustainable supply chain management - dynamic capabilities

\section{Introduction}

Conceived of twenty years ago [1] the natural resource based view (NRBV) resonates strongly with today's markets [2] and still features prominently in modern literature [3]. The NRBV attempts to address issues of ecological and societal degradation via four symbiotic resources that render competitive benefits for the firm with regards to cost, quality, efficiency and differentiation [1], [4]. However, in spite of a strong literary following and academic praise [3], [5], [6], [7] the theory is victim to one major criticism: a lack of practical applicability [8]. In the most part this is attributed to insufficient academic attention as to the capabilities required to support NRBV resources [4], conflicting the intrinsic nature of resources and capabilities [9]. Thus, via extensive literature review and empirical investigation we present a framework to guide the practical realization on the NRBV.

The construction of a conceptual capability framework is derived from three literary fields, which are discussed in some detail in this paper. Firstly seminal NRBV studies are reviewed, highlighting a number of implications for possible capabilities. Secondly the NRBV's synergistic relationship with sustainable supply chain management (SSCM) [3] is explored, permitting the identification and capabilities which 
may be of relevance to the NRBV. Finally, dynamic capabilities are used to categorize capabilities into activities of sensing, seizing and transforming [10] in accordance with the widely accepted argument that resource based theories lack applicability without dynamic capabilities [4], [11], [12].A qualitative multiple-interview methodological approach is then employed explore the framework within the context of the Scottish agri-food sector, resulting in an empirically enforced definition of NRBV capabilities. The following research objectives are set:

- Identify NRBV capabilities from a review of seminal studies;

- explore the synergistic topic of SSCM to draw out additional capabilities;

- categorizing these capabilities according to dynamic capabilities create a conceptual framework;

- and assess and refine the framework via empirical investigation of the agri-food sector

\section{$2 \quad$ Literature Review}

\subsection{The Natural-Resource-Based View}

The NRBV traditionally consisted of three symbiotic resources, namely pollution prevention, product stewardship and sustainable development, and emerged in response to the realization that sustainable operations may offer competitive advantage [1]. Whilst pollution prevention exists as the dominant resource [5], [6], closely followed by product stewardship [2], sustainable development suffered considerable neglect and misinterpretation [4], [12] resulting in a subsequent division into clean technologies [13] and base of the pyramid (BoP) [14]. Given the desire to ease issues of inapplicability this study is inclusive of pollution prevention, product stewardship, clean technologies and BoP, in what we term the 'four resource perspective'.

Pollution prevention supports the minimization of waste and emissions in internal production and is presented as a strategy of great significance in modern business [16]. By shifting waste management from control towards prevention firms are expected to benefit from improved efficiency and productivity and reduced costs [1] [5]. In its initial conception pollution prevention capabilities, aside from environmental management systems (EMS), are entirely neglected. A later review of the topic offers greater insight, highlighting employee skills and participation, organizational commitment, cross-functional integration, technology, human resource management and political acumen as pollution prevention capabilities [5]. More recently, continuous improvement is defined as the resource's fundamental capability [4], [16], [17], [18].

Product stewardship offers advancement for pollution prevention [13] in that it extends the prioritization of the natural throughout the entire product lifecycle rather than just within the firm [1]. From this perspective the natural environment is a key stakeholder, and firms are expected to benefit economically and environmentally via the creation of wholly sustainable products and processes [1], [12]. With regards to capabilities an emphasis is placed on cross-functional management, stakeholder management, and lifecycle analysis [1]. The significance of lifecycle analysis has since 
been reinforced [3], [17], but it is certainly notable that product stewardship capabilities have not been awarded the same attention as those of pollution prevention.

Clean technologies offers a further advancement of both pollution prevention and product stewardship, in that whilst pollution prevention and product stewardship aim to reduce impact or realize zero impact operations, clean technologies works towards positive impact operations [4] . More specifically, it is argued that companies must be receptive to future technologies [13], encouraging a shift away from traditional routines and processes and calling for the creative redesign of industries to support sustainability [19]. With regards to capabilities entrepreneurial capabilities, organizational vision and future positioning and commercialization capabilities [4], [19] are emphasized. Political acumen is also linked with clean technologies [20].

BoP can be presented as the socially focused counterpart of sustainable development. It focuses upon the alleviation of social ills via stimulation of economic growth in and support of emerging markets [14]. BoP in its simplest form argues that engaging in business at the bottom of the pyramid may ease poverty whilst simultaneously increasing profits by targeting previously neglected and unsaturated markets [19]. For this to succeed products and services may need to be specifically designed to suit unfamiliar needs [14]. As such capabilities such as technological innovation [21], external collaboration [21], entrepreneurship and the radical modification of business models and processes [26] are linked with BoP.

\subsection{NRBV Extensions and Developments}

The prominence of the NRBV in academia has resulted in several attempts at theoretical extension and development. The first comes from Aragon-Correa \& Sharma [6] in which a contingent proactive environmental strategy in presented to assist the realization of pollution prevention. Their paper argues the need for a proactive approach to the environment in pollution prevention, and pertinently highlights stakeholder integration, continuous improvement, higher order shared learning, the interpretation of environmental issues as opportunities, and the reconfiguration and recombination of resources as the necessary capabilities to support such an approach. A second attempt comes from Mencug \& Ozanne [8] and their natural environment orientation which aims to add approachability to pollution prevention, product stewardship and Hart's original sustainable development. Their paper presents corporate social responsibility inspired measurements to pollution prevention; proactive management, risk-taking and entrepreneurship to product stewardship; and internal reporting, environmental audits and reviews, internal environmental rewards and employee training to sustainable development. The third attempt comes from Shi et al [2] and builds upon links between green supply chain management (GSCM) and pollution prevention and product stewardship to create the NRB-GSCM model [2]. The model links pollution prevention with environmental policy, consideration of environmental criteria, process optimization, internal environmental management procedures and advanced prevention and safety methods. Product stewardship is linked with green purchasing, green distribution and design for the environment. 


\subsection{The NRBV and SSCM}

There exist notable links between the NRBV and supply chain management throughout literature [3], [4], [12]. Whilst this has already manifested in the NRBGSCM model [2], we propose an amalgamation with SSCM on account its inclusion of both ecological and social principles which corresponds with our four resource perspective of the NRBV. In addition, SSCM's widespread industry acceptance and application [12] may offer some resolve to the NRBV's issues of practical inapplicability and managerial avoidance.

Pollution prevention and SSCM can be linked easily via their paralleled intentions of waste management, encouraging existing studies to consider the role of environmental management systems and lean [27] in pollution prevention. Links between product stewardship and SSCM are already noted to some extent in the NRB-GSCM model in which green purchasing, green distribution and design for the environment are prioritized [2], but synergies have also been noted with regards to supply chain collaboration [18], leading to consideration of capabilities such as stakeholder integration, inter-organizational learning and joint sustainable innovation. Clean technologies has been compared with SSCM's environmental technologies [28] rendering consideration supply chain aptitude for new technologies, employee training and technological management systems. Closed-loop SCM [12], [19], corporate environmental responsibility [15] and resource efficient supply chains [7] have also been linked with clean technologies. BoP corresponds with discussion of socially responsible SCM [15] and SCM in developing economies [7], rendering consideration of capabilities such as supplier training and capacity building, shared culture, exploitation of external opportunities and strategic market entry. Links with external collaboration also warrant consideration of social embeddedness and joint planning for societal objectives [21].

\subsection{The NRBV and Dynamic Capabilities}

It is commonly argued resource-based theories lack adaptability [11] and that in order to avoid irrelevance or invalidity in turbulent markets resources must continuously evolve [22]. Teece's dynamic capabilities emerged in response to this, encouraging firms to adapt to rapidly changing environments via the continuous development of organizational competencies [23]. Dynamic capabilities were well received in literature, and have been credited with overcoming one of the major flaws on the NRBV [4], [6]. This said they are in their own right criticized for lacking practical applicability for failing to offer specific definition of a dynamic capability [6]. Resolving this in a later paper, Teece argues that dynamic capabilities cannot be defined and should not be seen as an 'add on' to the NRBV [10]. Instead, dynamic capabilities, which are divided into categories of sensing, seizing and transforming activities, should be used to describe and guide NRBV capabilities. Given the purpose of this study is to guide NRBV application this is a philosophy to which we conform. 
Table 1. Dynamic natural-resource-based capabilties for SSCM

\begin{tabular}{|c|c|c|c|}
\hline & $\begin{array}{l}\text { Sensing } \\
\text { (seek \& shape oppor- } \\
\text { tunities) }\end{array}$ & $\begin{array}{l}\text { Seizing } \\
\text { (implementing \& managing } \\
\text { new opportunities) }\end{array}$ & $\begin{array}{l}\text { Transforming } \\
\text { (organizational evolution) }\end{array}$ \\
\hline $\mathbf{P P}^{*}$ & $\begin{array}{l}\text { - Employee aware- } \\
\text { ness [5] } \\
\text { - Political acumen [5] } \\
\text { - Proactive approach } \\
\text { to the environment } \\
\text { [6], [8] } \\
\text { - Stakeholder inte- } \\
\text { gration [6] } \\
\text { - Higher order shared } \\
\text { learning [6] } \\
\text { - Consideration of } \\
\text { environmental crite- } \\
\text { ria }\end{array}$ & $\begin{array}{l}\text { - EMS [1], [27] } \\
\text { - Employee skills [5] } \\
\text { - Technological knowhow } \\
\text { [5] } \\
\text { - Resource reconfiguration/ } \\
\text { management [6] } \\
\text { - Performance measurement } \\
\text { [8] } \\
\text { - Environmental policy [2] } \\
\text { - Internal environmental } \\
\text { management procedures [2] }\end{array}$ & $\begin{array}{l}\text { - Continuous improvement } \\
\text { [4], [6], [16], [17], [18] } \\
\text { - Organizational commit- } \\
\text { ment [5] } \\
\text { - Cross functional integra- } \\
\text { tion [5] } \\
\text { - Human resource manage- } \\
\text { ment [5] } \\
\text { - Process optimization [2] } \\
\text { - Advanced prevention \& } \\
\text { safety methods [2] } \\
\text { - Lean [27] }\end{array}$ \\
\hline PS* & $\begin{array}{l}\text { - Stakeholder inte- } \\
\text { gration [1] } \\
\text { - Lifecycle analysis } \\
\text { [1] [3] [17] } \\
\text { - Risk taking [8] } \\
\text { - Proactive approach } \\
\text { to the environment } \\
\text { [8] } \\
\text { - Inter-organizational } \\
\text { learning [18] }\end{array}$ & $\begin{array}{l}\text { - Collaborative supply chain } \\
\text { relationships [1], [18] } \\
\text { Cross functional manage- } \\
\text { ment [1] } \\
\text { - Green purchasing [2] } \\
\text { - Green distribution [2] } \\
\text { - Reverse Logistics [12] }\end{array}$ & $\begin{array}{l}\text { - Stakeholder management } \\
\text { [1] } \\
\text { - Long term (lifecycle) } \\
\text { perspective [1] } \\
\text { - Design for the environ- } \\
\text { ment [2] } \\
\text { - Joint sustainable innova- } \\
\text { tion [18] }\end{array}$ \\
\hline CT $^{*}$ & $\begin{array}{l}\text { - Organizational } \\
\text { vision [4], [19] } \\
\text { - Political acumen } \\
\text { [20] } \\
\text { - Environmental } \\
\text { audits [8], [7] } \\
\text { - Rewards for envi- } \\
\text { ronmental ideas [8] }\end{array}$ & $\begin{array}{l}\text { - Aptitude for new technolo- } \\
\text { gies [4], [28] } \\
\text { - Commercialization [4], [19] } \\
\text { - Internal reporting [8] } \\
\text { - Employee training [8], [28] } \\
\text { - Technological management } \\
\text { systems [28] } \\
\text { - Closed loop supply chain } \\
\text { management [12] }\end{array}$ & $\begin{array}{l}\text { - Creative redesign of indus- } \\
\text { tries [19] } \\
\text { - Future positioning [4], [19] } \\
\text { - Corporate environmental } \\
\text { responsibility [15] }\end{array}$ \\
\hline BoP $^{*}$ & $\begin{array}{l}\text { - External collabora- } \\
\text { tion [21] } \\
\text { - Environmental } \\
\text { audits [8] } \\
\text { - Internal rewards for } \\
\text { environmental ideas } \\
\text { [8] } \\
\text { - Joint planning for } \\
\text { social objectives [21] }\end{array}$ & $\begin{array}{l}\text { - Technological innovation } \\
\text { [21] } \\
\text { - Development of new busi- } \\
\text { ness models \& processes [26] } \\
\text { - Internal \& external report- } \\
\text { ing [8] } \\
\text { - Employee \& supplier train- } \\
\text { ing [7] [8] }\end{array}$ & $\begin{array}{l}\text { - Aptitude for radical } \\
\text { change [26] } \\
\text { - Integration [21] } \\
\text { - Shared culture [7], [15] } \\
\text { - Capacity building [7], [15] }\end{array}$ \\
\hline
\end{tabular}

${ }^{*}$ PP, Pollution Prevention; PS, Product Stewardship; CT, Clean Technologies; BoP, Base of the Pyramid 


\section{Research Design}

Adopting a deductive approach, the framework is then empirically tested via a twostage qualitative methodological approach. The first stage being exploratory analysis of the Scottish agri-food sector involving both primary and secondary data, and the second stage being multiple in-depth, semi structured interviews with purposefully selected Scottish agri-food companies. The Scottish agri-food sector was selected as a result of its high investment in sustainability [24], its prioritization of sustainability as a source of competitiveness [24] and its heavy reliance on natural resources [25].

Exploratory analysis of the Scottish agri-food sector began with the collection and review of secondary data from media, NGO and company websites and recent government policy and legislation. The purpose of this was to assess the extent to which each of the NRBV's four resources assumed relevance throughout the sector via identification of any NRBV traits. Alongside analysis of secondary data we also conducted eight telephone interviews during our exploratory analysis. These took place with Scottish agri-food companies who demonstrated particularly strong interests in sustainability. Avoiding the use of any NRBV or SSCM terminologies, companies are asked to discuss and describe their approach to and experiences of sustainability. This acted as a pilot study and facilitated the identification and inclusion of additional capabilities, namely vertical integration, ISO 14001 and family-based principles.

To complete the study multiple in-depth, semi-structured interviews are undertaken with Scottish agri-food companies. The purpose of this is to facilitate the empirical reinforcement or rejection of the NRBV capabilities drawn out from literature. Companies are purposefully selected according to their operations' resemblance to the NRBV. More specifically, we approached companies who promoted use of strategies comparable to pollution prevention, product stewardship clean technologies and BoP. Naturally chosen companies require a strong relationship with sustainability, and as such we were particularly drawn to companies who had won awards related to sustainability or who had patented sustainable technologies or systems. Along with their presence in the Scottish agri-food sector, such characteristics acted as our only criteria, and we did not select based upon size, turnover or sub-sector. It is hoped that this will assist in an accurate representation of the Scottish agri-food sector, or rather a realistic agri-food chain. Interviews are semi-structured in the hope of facilitating a conversational approach to data collection in which the respondent is encouraged to lead the discussion. In doing so respondents are asked about their experiences of and approached to sustainability, allowing any supportive capabilities to emerge without bias or leading. In addition an observation approach is employed via the tour of company premises, in which again the respondent is encouraged to take control and highlight any operations of facilities which they feel support sustainability. Interviews typically last between 90 and 120 minutes and are recorded and later transcribed. The intention is to match strategies discussed during interviews to one of the four NRBV resources and then to identify which capabilities were linked with those strategies. To this point six interviews have taken place, the details of which can be seen in table 2 . 
Table 2: Participant Details

\begin{tabular}{|c|l|l|l|l|}
\hline Company & Description & Turnover & Employees & Person(s) interviewed \\
\hline 1 & $\begin{array}{l}\text { Potato grower/ } \\
\text { producer }\end{array}$ & $£ 175 \mathrm{~m}$ & 850 & $\begin{array}{l}\text { Environmental energy effi- } \\
\text { ciency officer }\end{array}$ \\
\hline 2 & Potato grower & $£ 180 \mathrm{~m}$ & 900 & $\begin{array}{l}\text { Growing manager \& Agron- } \\
\text { omist }\end{array}$ \\
\hline 3 & Potato Breeders & $£ 4 \mathrm{~m}$ & 15 & Chief Executive \\
\hline 4 & $\begin{array}{l}\text { Dairy farmer/ Ice- } \\
\text { cream Producer }\end{array}$ & $£ 11 \mathrm{~m}$ & 70 & $\begin{array}{l}\text { Marketing Director \& Fi- } \\
\text { nance Director }\end{array}$ \\
\hline 5 & $\begin{array}{l}\text { Seaweed Harvest- } \\
\text { er \& Producer }\end{array}$ & $£ 200,000$ & 10 & CEO, Marketing Executive \\
\hline 6 & $\begin{array}{l}\text { Potato Growers } \\
\text { f2.5m }\end{array}$ & 10 & $\begin{array}{l}\text { CEO \& Environmental Of- } \\
\text { ficer }\end{array}$ \\
\hline
\end{tabular}

\section{$4 \quad$ Preliminary Findings}

The results of the exploratory analysis suggest that all four of Hart's NRBV resources are employed in the Scottish agri-food sector, albeit in varying degrees. In line with the intended diffusion of the NRBV [13] and recent review of the theory [4] pollution prevention emerges as the dominant resource, followed by product stewardship, then clean technologies, and then BoP. .Whilst BoP could easily be identified in secondary data, it only featured in three of the eight exploratory phone interviews, and pertinently on a local rather than global level in some conflict to BoP's original conception [19]. Notably this corresponds with a recent review of the topic [26] in which it is suggested that that BoP exists predominantly in local communities. Pertinently, throughout discussion of such strategies, all eight companies referenced competitive benefits with particular emphasis on cost saving, and all eight companies relied heavily on supply chain terminologies to explain their approach to sustainability.

Whilst it is too early to definitively confirm or reject any of the capabilities drawn out from the literature review or exploratory analysis, preliminarily results of the interviews do imply strong correspondence. Every pollution prevention capability, with the exception of human resource management, features at some point throughout the six interviews. In addition, frequent discussion of ISO 14001 and company's specifically designed EMS throughout interviews add definition to the more obscure terms of EMS and internal environmental policy. Every product stewardship capability can be identified in interview transcripts, and in particular stakeholder integration, interorganizational learning and joint sustainable innovation feature prominently. In five of the six companies interviews respondents link this with supermarket led auditing systems, certification and participation in online forums, whilst four companies link it with government funding for collaborative projects. Discussion of green purchasing, distribution and reverse logistics invites further discussion of certification along with technologies such as free cooling and electronic tracking and carbon measurement. With the exception of commercialization, technological management systems and the 
creative redesign of industries, clean technology capabilities also demonstrate consistency between literature review and empirical findings. Closed loop supply chain management emerges with particular significance, whilst additional capabilities such as leadership and organizational creativity warrant discussion. Pertinently, as with the exploratory analysis, family principles and heritage emerge with significance with four of the companies claiming their ability to look beyond short term investments and for the sake of the next generation permitted the creation or adoption of clean technologies. Finally, BoP capabilities, with the exception of capacity building, feature in the interviews, albeit this is again on a local rather than global scale. In the most part such discussions include references to support of local charities, on site animal and wildlife conservation projects and lobbying for local causes. As such external collaboration, joint planning for social objectives and shared culture assume dominance, whilst family principles and heritage again emerge with relevance.

Table 3: Preliminary Results

\begin{tabular}{|c|c|c|c|}
\hline & Sensing & Seizing & Transforming \\
\hline $\mathbf{P P}^{*}$ & $\begin{array}{l}\text { - Employee awareness } \\
\text { - Political acumen } \\
\text { - Proactive approach to } \\
\text { the environment } \\
\text { - Stakeholder integration } \\
\text { - Shared learning } \\
\text { - Consideration of envi- } \\
\text { ronmental criteria }\end{array}$ & $\begin{array}{l}\text { - Purpose built EMS } \\
\text { - Employee skills } \\
\text { - Technological know how } \\
\text { - Resource management } \\
\text { - Performance measurement } \\
\text { - ISO } 14001\end{array}$ & $\begin{array}{l}\text { - Continuous improvement } \\
\text { - Organizational commit- } \\
\text { ment } \\
\text { - Cross functional integra- } \\
\text { tion } \\
\text { - Process optimization } \\
\text { - Advanced safety methods } \\
\text { - Lean }\end{array}$ \\
\hline PS $^{*}$ & $\begin{array}{l}\text { - Stakeholder integration } \\
\text { - Inter-organizational } \\
\text { learning } \\
\text { - Participation in online } \\
\text { forums } \\
\text { - Lifecycle analysis } \\
\text { - Risk taking } \\
\text { - Proactive approach }\end{array}$ & $\begin{array}{l}\text { - Collaborative supply chain } \\
\text { relationships } \\
\text { - Vertical integration } \\
\text { - Green purchasing } \\
\text {-Distribution/ logistic tech- } \\
\text { nologies } \\
\text { - Government funding } \\
\text { - Carbon measurement }\end{array}$ & $\begin{array}{l}\text { - Joint sustainable innova- } \\
\text { tion } \\
\text { - Stakeholder management } \\
\text { - Certification } \\
\text { - Design for the environ- } \\
\text { ment } \\
\text { - Relationship with super- } \\
\text { market }\end{array}$ \\
\hline CT $^{*}$ & $\begin{array}{l}\text { - Organizational vision } \\
\text { - Political acumen } \\
\text { - Environmental audits } \\
\text { - Internal environmental } \\
\text { rewards } \\
\text { - Organizational creativi- } \\
\text { ty }\end{array}$ & $\begin{array}{l}\text { - Aptitude for technologies } \\
\text { - Internal reporting } \\
\text { - Employee training } \\
\text { - Closed loop supply chains } \\
\text { - Leadership } \\
\text { - Family management }\end{array}$ & $\begin{array}{l}\text { - Future positioning } \\
\text { - Corporate environmental } \\
\text { responsibility } \\
\text { - Long term perspective } \\
\text { - Detachment from short } \\
\text { term financial returns }\end{array}$ \\
\hline $\mathbf{B o P}^{*}$ & $\begin{array}{l}\text { - External collaboration } \\
\text { - Environmental audits } \\
\text { - Internal environmental } \\
\text { rewards } \\
\text { - Joint planning for so- } \\
\text { cial objectives }\end{array}$ & $\begin{array}{l}\text { - Technological innovation } \\
\text { - Internal \& external report- } \\
\text { ing } \\
\text { - Employee/ supplier train- } \\
\text { ing } \\
\text { - Family management }\end{array}$ & $\begin{array}{l}\text { - Aptitude for radical } \\
\text { change } \\
\text { - Integration } \\
\text { - Shared culture } \\
\text { - Long term perspective }\end{array}$ \\
\hline
\end{tabular}

* PP, Pollution Prevention; PS, Product Stewardship; CT, Clean Technologies; BoP, Base of the Pyramid 


\section{Conclusions}

Although research is yet to be completed, preliminary results appear positive and support the value of this study. High levels of consistency between the conceptual framework of dynamic natural resource based capabilities and empirical analysis suggests that the amalgamation of the NRBV, SSCM and dynamic capabilities is logical and offers a long overdue guide to the adoption and management of competitive and sustainable operations. Whilst this is of course the principle aim of this study, several contributions are sought: first to refine twenty years of NRBV and related literature; secondly to respond to calls for the definition of supportive NRBV capabilities [4]; and thirdly to support the continued development of sustainable operations in the Scottish agri-food sector.

\section{References}

1. Hart, S.L.: A natural-resourced-based view of the firm. AMR. 20, 4, 986-1014 (1995)

2. Shi, V.G., Koh, L., Baldwin, J., Cucchiella, F.: Natural resource based green supply chain management. Supply Chain Manag. 17 , 1, 54-67 (2012)

3. Johnsen, T.E., Howard, M., Miemczyk, J.: Purchasing and supply chain management: a sustainability perspective. London: Routledge (2014)

4. Hart, S.L., Dowell, G.: A natural-resource-based view of the firm: fifteen years after. JOM. 37, 5, 1464-1479 (2011)

5. Russo, M.V., Fouts, P.A.: A resource-based perspective on corporate environmental performance and profitability. AMJ. 40, 3, 534-559 (1997)

6. Aragon-Correa, J.A., Sharma, S.: A contingent resource-based view of proactive corporate environmental strategy. AMR. 28, 1, 71-88 (2003)

7. Matopolous, A., Barros, A.C., Van der Vorst, J.: Resource-efficient supply chains: a research framework, literature review and research agenda'. SCM J. 2, pp218-236 (2014)

8. Menguc, B., Ozanne, L.K.: Challenges of the 'green imperative': a naturalresource-based approach to the environmental orientation-business performance relationship. JBR. 58, 4, 440-438 (2005)

9. Barney, J.B.: Firm resources and sustained competitive advantage. JOM. 17, 1, pp99-120 (2001)

10. Teece, D.J.: Explicating dynamic capabilities: the nature and micro-foundations of (sustainable) enterprise performance. SMJ. 28, 13, 1319-1350 (2007)

11. Fiol, C.M.: Revisiting an identity-based view of sustainable competitive advantage. JOM. 27, 6, 691-699 (2001)

12. Ashby, A., Leat, M., Hudson-Smith, M.: Making connections: a review of supply chain management and sustainability literature. Supply Chain Manag. 17, 5, 497$516(2012)$

13. Hart, S.L.: Beyond greening: strategies for a sustainable world. HBR. 75, 1, 6875 (1997) 
14. Hart, S.L., Christensen, C.M: The great leap: Driving innovation form the base of the pyramid. MIT Sloan Management Review. 44, 1, 51-56 (2002)

15. Markley, M.J., Davis, L.: Exploring future competitive advantage through sustainable supply chain management. Int. J. Phys. Dist. Log. 37, 9, 763-774 (2007)

16. Golicic, S., Smith, C.D.: A meta-analysis of environmentally sustainable supply chain management practices and firm performance. JSCM. 49, 2, 78-95 (2013)

17. Christmann, P.: Effects of "best practices" of environmental management on cost advantage: the role of complementary assets. AOM. 43, 4, 663-680 (2000)

18. Vachon, S., Klassen, R.D.: Environmental management and manufacturing performance: The role of collaboration in the supply chain. Int. J. Prod. Econ. 111, 2, 299-315 (2008)

19. Hart, S.L., Milstein, M.B.: Global sustainability and creative destruction of industries. Sloan Manag. Rev. 41, 1, 23-33 (1999)

20. Bjornali, E.S., Ellingsen, A.: Factors effecting the development of clean-tech start-ups: a literature review. Energy Procedia. 58, 43-50 (2014)

21. Prahalad, C.K., Hart, S.L.: The fortune at the bottom of the pyramid. Stratrgy + Business. 26, 2, 1-23 (2002)

22. Eisenhardt, K.M., Martin, J.A.: Dynamic capabilities: what are they? Strategic Management J. 21, 10-11, 1105-1121 (2000)

23. Teece, D.J., Pisano, G., Shuen, A.: Dynamic capabilities and strategic management'. Strategic Management J. 18, 7, 509-533 (1997)

24. Scotland Food \& Drink: Making the Link: How sustainability equals success. http://www.scotlandfoodanddrink.org/industry/sustainability.aspx

25. Food \& Health Innovation Service: Eating for Health and Sustainability.http://www.foodhealthinnovation.com/media/6979/eating_for_health_and_sus tainability_february_2013_.pdf

26. Kolk, A., Rivera-Santos, M., Rufin, C.: Reviewing a decade of research on the base/bottom of the pyramid (BoP) concept. Business Society. 53, 3, 338-377 (2014)

27. Hajmohammad, S., Vachon, S., Klassen, R.D., Gavronski, L.: Lean management and supply management: their role in green practices and performance. J. Clean Prod. 39, 1, 312-320 (2012)

28. Schrettle, S., Hinz, A., Scherrer-Rathje, M., Friedli, T.: Turning sustainability into action: explaining firms' sustainability efforts and their impact on performance. Int. J. Prod. Econ. 147, 73-84 (2014) 